\title{
Use of the Tinetti Index to Assess Fall Risk in Patients with Sequelae of Stroke
}

\author{
Zuila Maria de Figueiredo Carvalho ${ }^{*}$, Joyce Miná Albuquerque Coelho', \\ Raelly Ramos Campos, Deyse Cardoso de Oliveira1, Winner Gomes Machado1, \\ Samia Jardelle Costa de Freitas Maniva ${ }^{1,2}$ \\ ${ }^{1}$ Federal University of Ceará, Fortaleza, Brazil \\ ${ }^{2}$ Fortaleza General Hospital, Fortaleza, Brazil \\ Email: zmfca@fortalnet.com.br, joyminah@yahoo.com.br, raellyramos@hotmail.com, \\ deysecard@yahoo.com.br, winnergomes@gmail.com, samia.jardelle@gmail.com
}

Received 9 October 2014; revised 26 November 2014; accepted 11 December 2014

Copyright (C) 2014 by authors and Scientific Research Publishing Inc.

This work is licensed under the Creative Commons Attribution International License (CC BY).

http://creativecommons.org/licenses/by/4.0/

(c) (i) Open Access

\begin{abstract}
Background and Objective: The knowledge about risk of falls in patients with sequelae of stroke by applying a scale constitutes an important factor fort nurses since it allows planning for quality care and consequently improves the quality of life of such patients. The present study aimed to assess the risk of falls of patients with sequelae of stroke using Tinetti Index. Methods: Transversal descriptive study with 61 hospitalized patients. The data were collected through the application of Tinetti Index, the total score of which is 28 points. Results: The index evaluation shows que $47.9 \%$ had 19 points under the ideal score, indicating a high risk of falls, $41.7 \%$ from 24 to 28 , indicating moderate risk and $10.4 \%$ from 19 to 23 points, indicating low risk of falls. The final average was $(15.23)$, the median $(16.50)$ and standard deviation $( \pm 11.034)$. Conclusions: There is a high risk of falls in this population, a quantification of impaired balance and gait anticipate the future risk of falls. The use of assessment instruments has important implications for improving the quality of life in patients with symptomatic stroke.
\end{abstract}

\section{Keywords}

Tinetti Index, Sequelae of Stroke, Risk of Falls, Nursing

\section{Introduction}

Brain Stroke is a disease characterized by acute onset of a neurological deficit persisting for at least 24 hours.

${ }^{*}$ Corresponding author.

How to cite this paper: de Figueiredo Carvalho, Z.M., et al. (2014) Use of the Tinetti Index to Assess Fall Risk in Patients with Sequelae of Stroke. J. Biomedical Science and Engineering, 7, 1088-1094. http://dx.doi.org/10.4236/jbise.2014.714106 
Such a condition reflects the involvement of the central nervous system, which makes them have a disturbance of function in the cerebral circulation, causing reduction of the supply of oxygen and glucose to the brain cells, with subsequent death of these cells [1].

Due to its cause, the stroke can be classified into: ischemic, when the blood supply to the brain is interrupted or hemorrhagic, when a blood leakage occurs in the subarachnoid or intra parenchymal space resulting in complicating factors, like the occurrence of non-focal lesions and the increase intracranial pressure. In both cases, it sets to be a disease of major repercussions for Public Health [2], for resulting comorbidities as well as behavioral factors that influence the incidence of diseases: high blood pressure, smoking, inadequate feeding, inactivity as well as socio-ecological issues.

Currently, stroke is considered the third cause of death in the World, occurring mainly with male people, with African American Descents and people over 65 years old [3]-[5]. In Brazil it is considered the first cause of mortality and disability in adults, highlighting that in the year 2003, Northeastern Brazil, the rate of mortality from this disease has come to 54.6/100,000 inhabitants [6].

Neurological deficits due to side becomes apparent deterioration in the quality of life of patients [7], indeed justified by at least two-thirds of survivors remain with some degree of disability, becoming dependent mainly to speak, to walk, to see or even to feel and sometimes unable to exercise their daily activities [8] [9]. Among those with stroke sequelae, the study Aguiaretal. [10] highlighted the body asymmetrical and the postural imbalance like factors that may directly affect the person's ability to perform activities of daily living (ADL), necessary routine activities for getting by.

This issue has been sought new strategies for health evaluation of patients with victims of stroke in order to guide the identification of their real and potential needs in order to prevent or reduce impairments that may interfere in the quality of life of the patients and their families. In this context, the test of balance and gait developed by Mary Tinetti, Richman, and Powell [11] is highlighted. It is an instrument to evaluate vestibular conditions and the gait of the patients. Since then, it has been known as Tinetti index. In 2003, such test was adapted by Silva and Matsura [12] to be used in Brasilian institutionalized population. Tinetti index does not require sophisticad equipment to be applied and it is trusted to detect significant changes during the gait. The usage of this assessment tool has important implications for quality of life, as it enables prevention, care and rehabilitation [13].

This study is relevant for Nursing, because Tinetti index application in patients with symptomatic stroke will allow better evaluation of such patients, especially to balance, coordination and agility gait, thus demonstrating that the Nurse has an important role in identifying the needs of the patients. It is hoped by the applicability of this scale in the health center unit it is possible to evaluate the physical mobility of patients affected by stroke, as well as identify the main mobility difficulties and the risk of accidents in order for the nurses may manage later an intervention plan based on evidence. Therefore, this study aimed to evaluate the risk of falls in patients with stroke using the Tinetti Index.

\section{Methods}

\subsection{Design}

This is a descriptive, transversal study of a quantitative approach. The people participation on this study was of individuals with a diagnosis of stroke hospitalized admitted in the intensive care unit of a major hospital in the care of stroke patients in Fortaleza, Ceará.

\subsection{Participants}

The sample of such study was obtained by contingency, involving 48 patients who met the following inclusion criteria: having a diagnosis of stroke; be preserved to the level of awareness because of the commands of the scale; having hemodynamic conditions of balance and gait because of the tests related to them. The exclusion criteria was conceded to those who were under analgesia, making it impossible to obey commands, as well as those with impaired balance and gait prior to the stroke, such as Parkinson's.

\subsection{Measurements}

Data collection took place from February to May 2013 using the application of Tinetti index [8], which, in turn, 
consists of two parts: The first seeks balance evaluation and it has nine items, totaling 19 points; the second corresponds to gait evaluation, and it has seven items corresponding to 12 points. In total the index has therefore 16 items matching together 28 points. All the scale items represent commands and assessment occurs by observation. For each item checked, the appraiser assigns a score between 0 and 2 points, depending on the assessed parameter. A total score lower than 19 points indicates fivefold higher for risk of falls, so the lower the total score the higher the risk of falls in patients evaluated [11].

\subsection{Data Analysis}

Data were organized in an Excel spreadsheet Microsoft Windows 2013 version and then imported into the Statistical Package for the Social Sciences System—SPSS, Version 19.0. The data were presented in tables, graphs, absolute numbers and percentages. The findings were discussed in light of relevant literature. The ethical aspects of the research were respected at all stages of the research project was approved by the Ethics Committee of the Hospital, Opinion No. 255551/2013.

\section{Results}

In this study, $54.1 \%$ of participants were male, and to $45.9 \%$ female, with an average of 51.19 years old and standard deviation of \pm 16.009 . Regarding the type of stroke, ischemic were $100 \%$.

For better understanding of the results, it is shown in Table 1, the aspects that were evaluated to determine the balance and gait, based on Tinetti index.

According to Table 1 among the 16 evaluated items the most prevalent ones will be highlighted, will be featured as those more prevalent. In items 1 - 9 the balance was evaluated and it is perceived that $79.2 \%$ have seated balance; $39.6 \%$ stand upright without using their arms; $60.4 \%$ stand at only one attempt; $54.2 \%$ stand at stable way at the first 5 seconds; $39.6 \%$ stand evenly without support nor base; $43.8 \%$ balanced at the game of three turns; $60.4 \%$ get out of balance when they closed their eyes; $54.2 \%$ when rotated $360^{\circ}$ showed discrete steps; $50 \%$ get out of balance when rotated $360^{\circ}$ and $50 \%$ remained stable; $64.6 \%$ when sat remained safe to the handling grave.

Items from 10 to 16 evaluate gait and it is noted that $66.6 \%$ start the gait without hesitation; at the length and the height of the steps on the right foot, $56.2 \%$ surpasses the left foot and $54.2 \%$ the foot is completely out of the ground; and height of steps with left foot, $54.2 \%$ surpasses the right foot and $54.2 \%$ the foot is completely out of the ground at the symmetry of the steps, $62.5 \%$ had different steps and $37.5 \%$ had similar steps. At the continuity of the steps, $58.3 \%$ had discontinuous steps $41.7 \%$ continuing Steps at the direction, $45.8 \%$ had expressive gait deviation; during the gait the body in $43.8 \%$ come without bending and balance without the arms support or any other kind of support, $70.8 \%$ kept the ankles apart during the gait, and 29.2\% ankles almost touch each other when they walk.

Following are willing, in Figure 1, the statistic description of Tinetti index application on the balance and gait assessment. In Figure 2, the global scores of Tinetti Index.

According to Figure 1, the balance, the average was (9.38), the median 11 and standard deviation of \pm 6.28 . For the gait obtained an average of (5.85), the median (5.5) and standard deviation \pm 5.028 . In total index media obtained was (15.23), the median of $16.5 \pm$ standard deviation 11.034. It can be inferred that: There were no significant statistical results.

In Figure 2, is observed that $47.9 \%$ of the patients that had a score under 19, thus, featuring so high risk of falls; $41.7 \%$ ranged from 24 to 28 points, low risk of falls and the other $10.4 \%$, between 19 and 23 points, moderate risk.

\section{Discussion}

This study points out the need to discuss some relevant aspects, in particular on the risk of falls, as well as some questions regarding the use of Tinetti Index in patients with stroke.

According to Costa et al. [14], the occurrence of falls is one of the health problems faced by both institutionalized elderly population as at home. Several factors are involved in this event, for example, problems in physical mobility, functional, visual and cognitive. These changes, in turn, are caused by physiological and inevitable process of aging, and are more pronounced when added to the complications of non-communicable chronic dis- 
Table 1. Assessment of balance and gait index according to Tinetti. Fortaleza, Ceará, Brazil, 2013.

\begin{tabular}{|c|c|c|c|}
\hline \multicolumn{4}{|l|}{ Rating Scale Balance* $^{*}$} \\
\hline & & f & $\%$ \\
\hline 1. Sitting balance & $\begin{array}{l}\text { Leans or slides in chair } \\
\text { Steady, safe }\end{array}$ & $\begin{array}{l}10 \\
38\end{array}$ & $\begin{array}{l}20.8 \\
79.2\end{array}$ \\
\hline 2. Rises from chair & $\begin{array}{l}\text { Unable to without help } \\
\text { Able, uses arms to help } \\
\text { Able without use of arms }\end{array}$ & $\begin{array}{l}14 \\
15 \\
19\end{array}$ & $\begin{array}{l}29.2 \\
31.2 \\
39.6\end{array}$ \\
\hline 3. Attempts to rise & $\begin{array}{l}\text { Unable to without help } \\
\text { Able, requires }>1 \text { attempt } \\
\text { Able to rise, } 1 \text { attempt }\end{array}$ & $\begin{array}{c}12 \\
7 \\
29\end{array}$ & $\begin{array}{l}25.0 \\
14.6 \\
60.4\end{array}$ \\
\hline $\begin{array}{l}\text { 4. Immediate standing } \\
\text { Balance (first } 5 \text { seconds) }\end{array}$ & $\begin{array}{l}\text { Unsteady (staggers, moves feet, trunk sway) } \\
\text { Steady but uses walker or other support } \\
\text { Steady without walker or other support }\end{array}$ & $\begin{array}{l}15 \\
7 \\
26\end{array}$ & $\begin{array}{l}31.2 \\
14.6 \\
54.2\end{array}$ \\
\hline 5. Standing balance & $\begin{array}{l}\text { Unsteady } \\
\text { Steady but wide stance and uses support } \\
\text { Narrow stance without support }\end{array}$ & $\begin{array}{l}17 \\
12 \\
19\end{array}$ & $\begin{array}{l}35.4 \\
25.0 \\
39.6\end{array}$ \\
\hline 6. Nudged ${ }^{* *}$ & $\begin{array}{l}\text { Begins to fall } \\
\text { Staggers, grabs, catches self } \\
\text { Steady }\end{array}$ & $\begin{array}{l}17 \\
10 \\
21\end{array}$ & $\begin{array}{l}35.4 \\
20.8 \\
43.8\end{array}$ \\
\hline 7. Eyes closed ${ }^{* *}$ & $\begin{array}{l}\text { Unsteady } \\
\text { Steady }\end{array}$ & $\begin{array}{l}29 \\
19\end{array}$ & $\begin{array}{l}60.4 \\
39.6\end{array}$ \\
\hline 8. Turning 360 degrees & $\begin{array}{l}\text { Discontinuous steps } \\
\text { Continuous } \\
\text { Unsteady (grabs, staggers) } \\
\text { Steady }\end{array}$ & $\begin{array}{l}26 \\
22 \\
24 \\
24\end{array}$ & $\begin{array}{l}54.2 \\
45.8 \\
50.0 \\
50.0\end{array}$ \\
\hline 9. Sitting down & $\begin{array}{l}\text { Unsafe (misjudged distance, falls into chair) } \\
\text { Uses arms or not a smooth motion } \\
\text { Safe, smooth motion }\end{array}$ & $\begin{array}{l}11 \\
16 \\
31\end{array}$ & $\begin{array}{l}22.9 \\
12.5 \\
64.6\end{array}$ \\
\hline \multicolumn{4}{|l|}{ Gait Assessment Scale ${ }^{* * *}$} \\
\hline & & f & $\%$ \\
\hline 10. Indication of gait & $\begin{array}{l}\text { Any hesitancy or multiple attempts } \\
\text { No hesitancy }\end{array}$ & $\begin{array}{l}16 \\
32\end{array}$ & $\begin{array}{l}33.4 \\
66.6\end{array}$ \\
\hline 11. Step length and height & $\begin{array}{l}\text { a) Right foot } \\
\text { Does not exceed the left foot } \\
\text { Beyond the left foot } \\
\text { Not completely out of the ground } \\
\text { Completely out of the ground } \\
\text { b) Left foot } \\
\text { Does not exceed the right foot } \\
\text { Exceeds the right foot } \\
\text { Not completely out of the ground } \\
\text { Completely out of the ground }\end{array}$ & $\begin{array}{l}21 \\
27 \\
22 \\
26 \\
\\
22 \\
26 \\
22 \\
26\end{array}$ & $\begin{array}{l}43.8 \\
56.2 \\
45.8 \\
54.2 \\
45.8 \\
54.2 \\
45.8 \\
54.2\end{array}$ \\
\hline 12. Step symmetry & $\begin{array}{l}\text { Right and left step length not equal } \\
\text { Right and left step length appear equal }\end{array}$ & $\begin{array}{l}30 \\
18\end{array}$ & $\begin{array}{l}62.5 \\
37.5\end{array}$ \\
\hline 13. Step continuity & $\begin{array}{l}\text { Stopping or discontinuity between steps } \\
\text { Steps appear continuous }\end{array}$ & $\begin{array}{l}28 \\
20\end{array}$ & $\begin{array}{l}58.3 \\
41.7\end{array}$ \\
\hline 14. Path & $\begin{array}{l}\text { Marked deviation } \\
\text { Mild/moderate deviation or uses w. aid } \\
\text { Straight without w. aid }\end{array}$ & $\begin{array}{l}22 \\
10 \\
16\end{array}$ & $\begin{array}{l}45.8 \\
20.8 \\
33.4\end{array}$ \\
\hline 15. Trunk & $\begin{array}{l}\text { Marked sway or uses w. aid } \\
\text { No sway but flex. knees or back or uses arms for stability } \\
\text { No sway, flex., use of arms or w. aid }\end{array}$ & $\begin{array}{c}19 \\
8 \\
21\end{array}$ & $\begin{array}{l}39.6 \\
16.7 \\
43.8\end{array}$ \\
\hline 16. Ankles distance & Separate ankles, ankles almost touch the floor & $\begin{array}{l}34 \\
14\end{array}$ & $\begin{array}{l}70.8 \\
29.2\end{array}$ \\
\hline
\end{tabular}

${ }^{*}$ Punctuation $=16 ;{ }^{* *}$ The external examiner gently pushes the patient, which should stand feet together; ${ }^{* * *}$ Punctuation $=12$. 


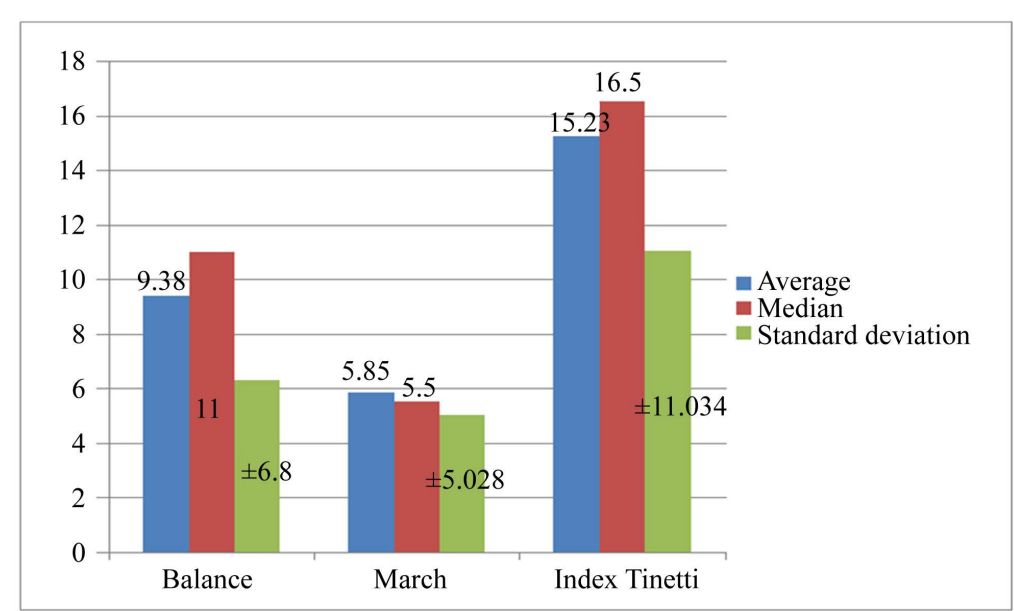

Figure 1. Assessment of balance, gait, and total score on the Tinetti Index. Fortaleza, Ceará, Brazil, 2013.

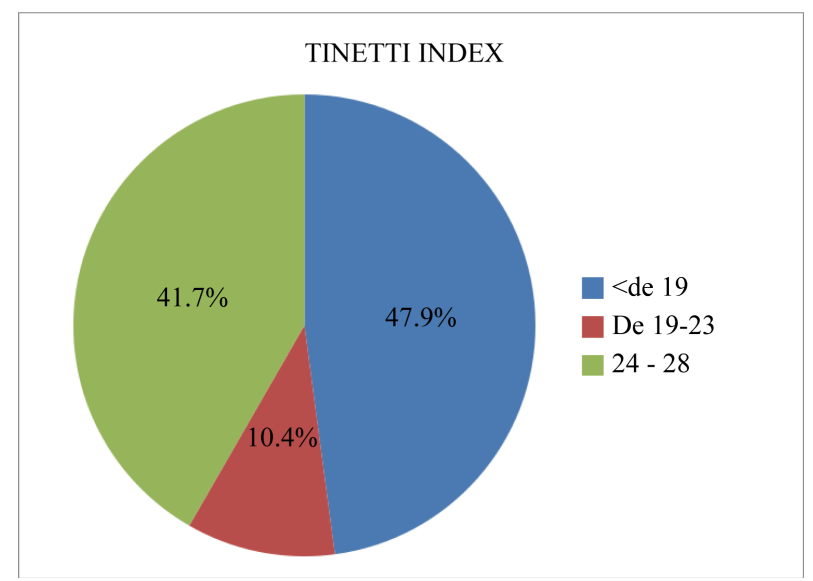

Figure 2. Tinetti assessment index as the risk of falls. Fortaleza, Ceará, Brazil, 2013.

eases. In this context, it is stroke, disabling disease of high potential which is more prevalent in age groups of 60 years or more and that can increase the risk of falls.

In this study, it is highlighted the following aspect: $41.7 \%$ of the patients achieved the total score lower than 19 points according to Tinetti Index, meaning high risk of falls [11]. This finding, in a sense, was expected, considering that people affected by stroke, depending on the location of ischemia, may exhibit postural imbalance, sensory changes, motor and mobility difficulties who directly commit the greater incidence of falls [15].

The study by Morais et al. [15], regarding the application of the index Tinetti, found results consistent with this study. Among 37 patients evaluated, $43.3 \%$ showed impaired physical mobility, indicating high risk of falls. At the time, the scale was administered to a population that belongs to a group of rehabilitation in the chronic phase of the disease, different from the study population. This fact may indicate that the risk of falls for patients suffering stroke begins at time of acute illness, remaining elevated during the chronic phase.

Costa et al. [14] found in his study that impaired balance contributes to the increased risk of falls, according to the application of the Tinneti scale, highlighted the fact that intrinsic factors are the most identified with the fall event. It was emphasized that further changes of static and dynamic postural balance influence the functional capacity of older adults living in the community and can be a significant risk factor of falls, thus influencing the quality of life of this population.

According to Oliveira et al. [16], this data is alarming and should serve as a warning to health care professionals and, since the vast majority of times a person experiences a situation of fall, impaired quality of life occurs. Therefore, efforts should improve the identification of the most vulnerable people to falls in order to pre- 
vent injury.

In a study by Borges, Marinho Filho and Mascarenhas [17] to check the environmental risk of fall, mentions that $56 \%$ of households had a high risk of falls for elderly as well as the balance difficulties presented by the patients with stroke, which points to a worrying condition about the risk of falls that are subject to these people.

Even with the implementation of Tinetti Index, 52.1\% of the assessed patients had scores between $19-28$ points, representing from low to moderate risk of falls. It is believed that this prevalence is related to the age of those involved, as this study found a mean age of 54.19 years, standard deviation of \pm 16.009 , i.e., people who do not have the mobility problems that is common with elderly. Senescence provides sensory disorders of balance, postural control, level of cognitive and motor response, which makes the individual more conducive to falls [18]. As in this study the average age of patients victims of stroke was lower than compared to the one was expected for the disease, the occurrence of low to moderate risk of falls in part of the study population can be justified.

When the results for each of the items it was observed that the scale assesses balance and gait, it was also observed that the average score corresponds respectively to 9.38 and 5.85 points. And related to index in general, there is an average score of participants of 15.23 points, which therefore points back to a high risk of falls in this population. This fact becomes relevant in studies such as Nogueiro et al. [19] showing that independence in activities of daily living is strongly related to the risk of falls. What shows that perhaps the study population requires a high degree of dependence.

In this direction, this study confirms the magnitude of falls in people with stroke sequelae, such as a public health phenomenon that considering the impact on the lives of its clientele in the healthcare system and represents social and economic costs. Based on these findings, it becomes necessary to establish measures to prevent falls, so acting etiological factors, either intrinsic or extrinsic character, to reduce the incidence and subsequently damaging consequences to the patient, thereby acting in promoting health of this elderly.

\section{Conclusion}

In conclusion, the Tinetti index enabled us to evaluate balance, coordination, and walking agility to determine fall risk in patients with sequelae of stroke and maximize the knowledge of nurses and nursing students in this regard. This can facilitate the planning of nursing care focused on the individual needs of each patient. The clinical evaluation of fall risk using appropriate scales constitutes an important tool for assessing the functional abilities of patients with stroke. The Tinetti index is such a scale that sheds light on the nuances of care for individuals with ambulatory difficulties.

\section{Conflicts of Interest}

The authors declare that there are no conflicts of interest regarding the publication of this paper.

\section{Acknowledgements}

The authors would like to thank the Institutional Program for Scientific Initiation Scholarship (PIBIC) of the National Council for Scientific and Technological Development (CNPq), the Dean of Research and Graduate Studies at the Federal University of Ceará (UFC), the Foundation for Scientific and Technological Development (FUNCAP) for their support in the form of Scientific Initiation and Master's Scholarships, and the Fortaleza General Hospital for the opportunity to develop this research.

\section{References}

[1] Pedreira, L.C. and Lopes, R.L.M. (2010) Home Care to the Elderly Who Had Stroke. Revista Brasileira de Enfermagem, 63, 837-840. http://dx.doi.org/10.1590/S0034-71672010000500023

[2] Dickson, V.V., Clark, R.A., Rebolo-Silva, E.R. and Buck, H.G. (2013) Self-Care and Chronic Disease, Nursing Research and Practice. Nursing Research and Practice, Article ID: 827409. http://dx.doi.org/10.1155/2013/827409

[3] O’Connell, B. and Baker, L. (2004) Managing as Carers of Stroke Survivors: Strategies from the Field. International Journal of Nursing Practice, 10,121-126. http://dx.doi.org/10.1111/j.1440-172X.2004.00469.x

[4] Go, A.S., Mozaffarian, D., Roger, V.L., et al. (2013) Heart Disease and Stroke Statistics—2013 Update: A Report from the American Heart Association. Circulation, 127, e6-e245. http://dx.doi.org/10.1161/CIR.0b013e31828124ad

[5] Castilla-Guerra, L., Serrano-Rodríguez, L., Alpanseque-Hoogesteyn, L., Fernández-Moreno, M.C. and Jiménez-Her- 
nández, M.D. (2013) Prehospital Care of Acute Stroke: Have We Really Improved. Revista Neurologia, 56, 255-256. http://www.neurologia.com/pdf/Web/5604/bh040255.pdf

[6] Moreira, R.P., Araújo, T.L., Cavalcante, T.F., Guedes, N.G., Lopes, M.V.O., Costa, A.G.S. and Chave, D.B.R. (2010) Stroke: Risk Indicators Profile. Revista Rede de Enfermagem do Nordeste, 1, 201-212. http://www.revistarene.ufc.br/revista/index.php/revista/article/view/381/pdf

[7] Barker-Collo, S., Feigin, V.L. and Dudley, M. (2007) Post-Stroke Fatigue-Where Is the Evidence to Guide Practice? Journal of the New Zealand Medical Association, 120, 1264. http://journal.nzma.org.nz/journal/120-1264/2780/

[8] Lessmannl, J.C., Conto, F., Ramos, G., Borenstein, M.S. and Meirelles, B.H.S. (2011) Nursing Activities in Self-Care and Rehabilitation of Patients Who Suffered Stroke. Revista. Brasileira de Enfermagem, 64, 198-202. http://dx.doi.org/10.1590/S0034-71672011000100030

[9] Andrade, L.M., Costa, M.F.M., Caetano, J.A., Soares, E. and Beserra, E.P. (2008) The Issue of Family Caregivers of Patients with Stroke. Revista da Escola de Enfermagem da USP, 43, 37-43.

[10] Aguiar, P.T., Rocha, T.N. and Oliveira, E.S. (2010) Scales of Trunk Control and Functional Outcome in Patients after Stroke. Acta Fisiatrica, 15, 160-164. http://www.actafisiatrica.org.br/default.asp?ed=24

[11] Tinetti, M.A., Richman, D. and Powell, L. (1990) Falls Efficacy as a Measure of Fear of Falling. Journal of Gerontology, 45, 239-243. http://www.ncbi.nlm.nih.gov/pubmed/2229948 http://dx.doi.org/10.1093/geronj/45.6.P239

[12] Silva, V.F. and Matsuura, C. (2002) Effects of Regular Physical Activity on the Cognitive Status and Prevention of Falls in the Elderly. Fitness Performance Journal, 3, 39-45. http://www.ncbi.nlm.nih.gov/pubmed/2229948

[13] Apóstolo, J.L.A. (2011) Tools for Assessment in Geriatrics (Geriatric Instruments). Doctoral Thesis, Escola Superior de Enfermagem de Coimbra/Portugal, Coimbra, $111 \mathrm{f}$.

[14] Costa, A.G.S., Oliveira, A.R.S., Moreira, R.P., Cavalcante, T.F. and Araujo, T.L. (2010) Identification of the Risk of Falls in Elderly Stroke Patients. Escola Anna Nery, 14, 684-689. http://dx.doi.org/10.1590/S1414-81452010000400005

[15] Morais, H.C.C., Holanda, G.F., de S. Oliveira, A.R., de S. Costa, A.G., Ximenes, C.M.B. and de Araujo, T.L. (2012) Identification of Nursing Diagnosis Risk of Falls in Elderly Patients with Stroke. Revista Gaúcha de Enfermagem, 33, 117-124.

[16] de S. Oliveira, A.R., de S. Costa, A.G., de Sousa, V.E.C., Moreira, R.P., et al. (2011) Pipelines for the Prevention of Patient Falls with Stroke. Revista Enfermagem UERJ, 19, 107-113.

[17] Borges, P.S., Marinho Filho, E.N. and Mascarenhas, C.H.M. (2010) Correlation between Balance and Home Environment as Risk of Falls in Elderly Patients with Stroke. Revista Brasileira Geriatria end Gerontologia, 13, 41-50. http://dx.doi.org/10.1590/S1809-98232010000100005

[18] Damázio, L.C.M., Oliveira, J.C., Marciano, E.D. and Pissolati, M.G. (2014) Evaluation of the Risk of Falls and Quality of Life of Elderly Patients with Stroke. Saúde, 40, 43-50.

[19] Nogueiro, A., Novo, A., Branco, D., Mendes, E. and Preto, L. (2010) Functional Potential and Downside Risk. https://bibliotecadigital.ipb.pt/handle/10198/2899 
Scientific Research Publishing (SCIRP) is one of the largest Open Access journal publishers. It is currently publishing more than 200 open access, online, peer-reviewed journals covering a wide range of academic disciplines. SCIRP serves the worldwide academic communities and contributes to the progress and application of science with its publication.

Other selected journals from SCIRP are listed as below. Submit your manuscript to us via either submit@scirp.org or Online Submission Portal.
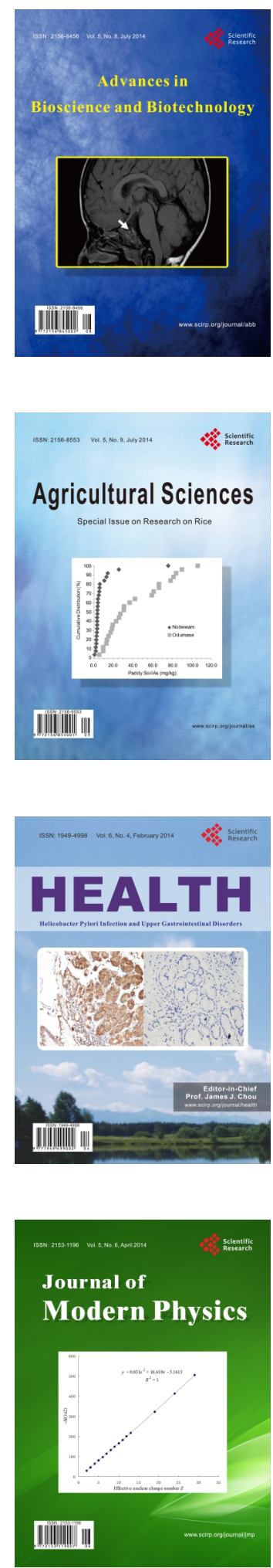
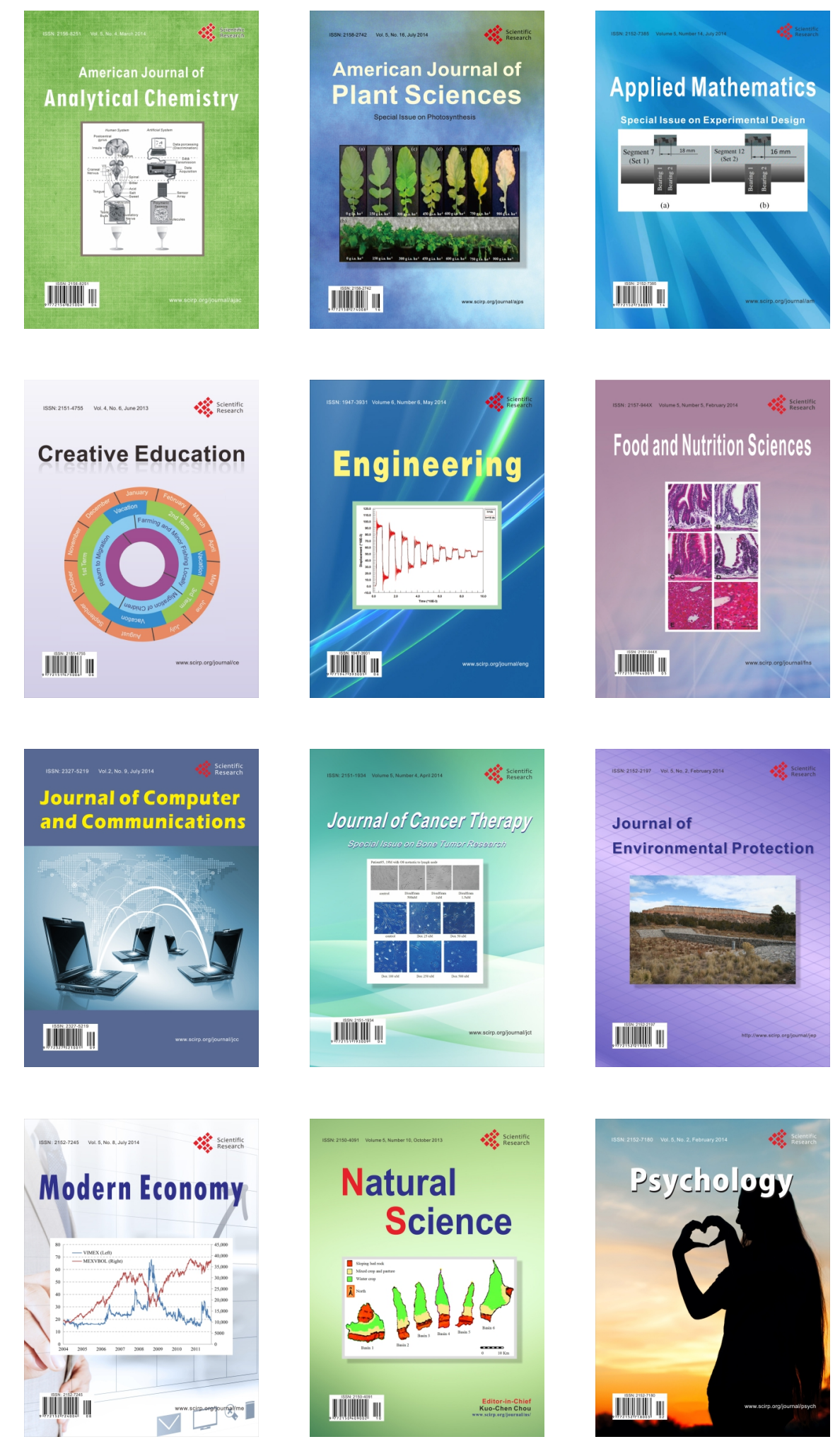